\title{
Apoptosis Enhances the Replication of Human Coronavirus OC43
}

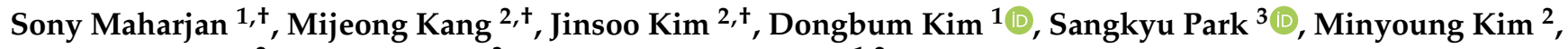 \\ Kyeongbin Baek ${ }^{2}$, Younghee Lee ${ }^{3, *}$ and Hyung-Joo Kwon ${ }^{1,2, *}$
}

1 Institute of Medical Science, College of Medicine, Hallym University, Chuncheon 24252, Korea; sonymaharjan3303@gmail.com (S.M.); hahadb@hallym.ac.kr (D.K.)

2 Department of Microbiology, College of Medicine, Hallym University, Chuncheon 24252, Korea; ekf780@naver.com (M.K.); rlawlstn8739@naver.com (J.K.); meany7@naver.com (M.K.); rudqls0905@naver.com (K.B.)

3 Department of Biochemistry, College of Natural Sciences, Chungbuk National University, Cheongju 28644, Korea; pucrim@nate.com

* Correspondence: yhl4177@cbnu.ac.kr (Y.L.); hjookwon@hallym.ac.kr (H.-J.K.); Tel..+82-33-248-2635 (H.-J.K.); Fax: +82-33-241-3640 (H.-J.K.)

+ These authors contributed equally to this work.

check for updates

Citation: Maharjan, S.; Kang, M.; Kim, J.; Kim, D.; Park, S.; Kim, M.; Baek, K.; Lee, Y.; Kwon, H.-J. Apoptosis Enhances the Replication of Human Coronavirus OC43. Viruses 2021, 13, 2199. https://doi.org/ 10.3390/v13112199

\section{Academic Editors:}

Luis Martinez-Sobrido and Fernando Almazan Toral

Received: 21 October 2021

Accepted: 29 October 2021

Published: 1 November 2021

Publisher's Note: MDPI stays neutral with regard to jurisdictional claims in published maps and institutional affiliations.

Copyright: (c) 2021 by the authors. Licensee MDPI, Basel, Switzerland. This article is an open access article distributed under the terms and conditions of the Creative Commons Attribution (CC BY) license (https:/ / creativecommons.org/licenses/by/ $4.0 /)$.

\begin{abstract}
Human coronavirus OC43 (HCoV-OC43) is one of the coronaviruses causing a mild common cold, but few studies have been made on this strain. Here, we identified the molecular mechanisms involved in HCoV-OC43-induced apoptosis and its implications for viral reproduction in Vero cells and MRC-5 cells. HCoV-OC43 infection induced apoptosis that was accompanied by cleavage of caspase- 3 and PARP, degradation of cyclin D1, and cell cycle arrest at $S$ and G2M phases. Dephosphorylation of STAT1 and STAT3, induced by HCoV-OC43 infection, was also associated with HCoV-OC43-mediated apoptosis. The pan-caspase inhibitor effectively prevented HCoV-OC43induced apoptosis and reduced viral replication, suggesting that apoptosis contributes to viral replication. Collectively our results indicate that $\mathrm{HCoV}-\mathrm{OC} 43$ induces caspase-dependent apoptosis to promote viral replication in Vero cells and MRC- 5 cells.
\end{abstract}

Keywords: HCoV-OC43; apoptosis; replication

\section{Introduction}

Coronaviruses (CoVs) are enveloped, positive-sense, single-stranded RNA viruses with a genome of approximately 26-32 kb. Seven strains of human coronaviruses (HCoVs) have been reported to cause mild to severe respiratory infections in humans [1]. The endemic strains HCoV-OC43 and HCoV-229E were first reported in the 1960s, and two new strains, HCoV-NL63 and HCoV-HKU1, were identified in 2004 and 2005, respectively; these HCoVs are known to cause about $15-30 \%$ of cases of the common cold [2,3] The first instance of a dangerous $\mathrm{CoV}$ as a human pathogen was severe acute respiratory syndrome (SARS) in 2003 with a 9.6\% mortality rate [4,5]. In 2012, another HCoV known as Middle East Respiratory Syndrome (MERS) caused an outbreak of a severe respiratory illness with a $37 \%$ mortality rate [6]. A novel CoV named SARS-CoV-2 emerged in December 2019 infecting 184 million people worldwide with over 4 million fatalities as of June 2021, establishing it as the worst global pandemic in human history [7].

$\mathrm{HCoV}-\mathrm{OC} 43$ is a strain that is frequently associated with upper respiratory tract infections and may exacerbate asthma and pneumonia [8,9]. It is occasionally found with other pathologies such as meningitis and enteritis [10,11] and is associated with lower respiratory tract disease and acute disseminated encephalomyelitis in children [12-14]. HCoV-OC43 has genes for four structural proteins, spike $(S)$, envelope $(E)$, membrane $(M)$, and nucleocapsid $(N)$, and an additional gene for an envelope-associated hemagglutinin 
esterase (HE) protein. Most research has focused on the pathology of SARS-CoV, MERS$\mathrm{CoV}$, and SARS-CoV-2, while few studies have been conducted on HCoV-OC43. The potential for coronaviruses to cross species barriers with significant mortality risks supports the need for new strategies to prevent and manage $\mathrm{HCoV}$ infections.

Apoptosis, or programmed cell death, is a regulated, multistep process that is essential for development, homeostasis, and protection against microbial infection [15]. Coronaviruses and many other viruses stimulate apoptosis during infection [16-20]. Apoptosis is an important antiviral defense of host cells that restricts the spread of infection by killing the virus-infected cells [21-23]. HCoV-OC43 induces apoptosis in human lung cells [18] but the underlying mechanisms of this response are not-well known. Here, we characterized apoptosis induced by $\mathrm{HCoV}-\mathrm{OC} 43$ infection in human lung fibroblast MRC-5 cells along with African green monkey kidney Vero cells. We also examined changes in signaling pathways after $\mathrm{HCoV}-\mathrm{OC} 43$ infection. Our study may shed light on the mechanisms involved in the pathophysiology of HCoV-OC43 infection.

\section{Materials and Methods}

\subsection{Cell Culture}

Vero cells were obtained from the Korean Cell Line Bank (Product \#10081, Seoul, Korea) and MRC-5 cells from the American Type Culture Collection (Product \#CCL-171, ATCC, Manassas, VA, USA). Vero cells and MRC- 5 cells were cultured in Dulbecco's modified Eagle's medium (DMEM, ATCC) and Eagle's Minimum Essential Medium (EMEM, ATCC), respectively, with 10\% fetal bovine serum (FBS, Thermo Fisher Scientific, Waltham, Massachusetts, USA), penicillin $(100 \mathrm{U} / \mathrm{mL})$, and streptomycin $(100 \mu \mathrm{g} / \mathrm{mL})$. Cells were maintained in $95 \%$ air and $5 \% \mathrm{CO}_{2}$ at $37^{\circ} \mathrm{C}$.

\subsection{Virus Amplification}

HCoV-OC43 (KBPV-VR-8) was obtained from the Korea Bank for Pathogenic Viruses (College of Medicine, Korea University, Seoul, Korea). HCoV-OC43 at a multiplicity of infection (MOI) of 0.03 was added to 6-well plates of Vero cells $\left(3 \times 10^{5}\right.$ cells/well) after washing with phosphate-buffered saline (PBS) and incubated for $1 \mathrm{~h}$ in a $5 \% \mathrm{CO}_{2}$ incubator at $37^{\circ} \mathrm{C}$ with shaking every $15 \mathrm{~min}$. After infection, the plates were maintained with 2 $\mathrm{mL}$ of DMEM containing $2 \% \mathrm{FBS}$ at $37{ }^{\circ} \mathrm{C}$ with $5 \% \mathrm{CO}_{2}$ and harvested at 4 days postinfection. The cell culture supernatants were centrifuged for $10 \mathrm{~min}$ at $3000 \mathrm{rpm}$ and cleared supernatants were aliquoted and stored at $-70{ }^{\circ} \mathrm{C}$. HCoV-OC43 amplification and cell culture were carried out under biosafety level 2 (BSL-2) conditions.

\subsection{Preparation of Virus-Infected Culture Supernatants}

Vero and MRC- 5 cells $\left(2 \times 10^{5}\right.$ cells/well) were seeded in 6-well plates in triplicate for each time point and MOI condition. The cells were washed with PBS or DMEM containing $10 \%$ FBS, and mock-infected or infected with HCoV-OC43 in PBS or DMEM containing $10 \% \mathrm{FBS}$ at an indicated $\mathrm{MOI}$ in a $5 \% \mathrm{CO}_{2}$ incubator at $37^{\circ} \mathrm{C}$ with shaking every $15 \mathrm{~min}$. After removing the medium, the cells were washed with PBS or DMEM containing $10 \%$ FBS. Then, $2 \mathrm{~mL}$ of DMEM (for Vero cells) or EMEM (for MRC-5 cells) containing $2 \%$ FBS or 10\% FBS was added to each well. Cell culture supernatants were harvested at the indicated time points and viral titer was measured using plaque assay and reverse transcriptase-quantitative PCR (RT-qPCR).

\subsection{Plaque Assay}

HCoV-OC43 was quantified by modification of a published plaque assay [24]. Briefly, Vero cells $\left(7 \times 10^{5}\right.$ cells / well) were grown in 6-well plates (Corning, NY, USA) for $18 \mathrm{~h}$. The cells were washed with PBS and infected with ten-fold serial dilutions of the virusinfected culture supernatants for $1 \mathrm{~h}$ in a $5 \% \mathrm{CO}_{2}$ incubator at $37^{\circ} \mathrm{C}$ with shaking every 15 min. After removing the medium, $3 \mathrm{~mL}$ DMEM/F12 medium (Thermo Fisher Scientific) mixed with $2 \%$ Oxoid agar was added to the wells. At 5 days post-infection, the overlay 
medium was removed, the cells were stained with $0.1 \%$ crystal violet, and washed to count plaque formation.

\section{5. $R T-q P C R$}

Viral RNAs were isolated from virus-infected cell culture supernatants $(100 \mu \mathrm{L})$ with QIAamp Viral RNA Mini Kit (Catalog No. 52904, Qiagen, Hilden, Germany) as described previously [25]. cDNA (50 $\mu \mathrm{L})$ was synthesized with a Reverse Transcription System kit (Catalog No. A3500, Promega, Madison, WI, USA). To quantify the nucleocapsid (N) gene of HCoV-OC43, the following primers were used (Kim et al., 2020). Forward primer, 5'-CGA TGA GGC TAT TCC GAC TAG GT-3' , reverse primer 5'-CCT TCC TGA GCC TTC AAT ATA GTA ACC-3', and TaqMan ${ }^{\circledR}$ Probe $5^{\prime}$-FAM-TCC GCC TGG CAC GGT ACT CCC T-TAMRA-3' [26]. The primers and the probe sequence were synthesized by Genotech (Daejeon, South Korea). GoTaq ${ }^{\circledR}$ Probe qPCR Master Mix $(10 \mu \mathrm{L})$ (Catalog No. A6101, Promega, Madison, WI, USA) was added to $10 \mu \mathrm{L}$ reaction mixture containing forward and reverse primers at $125 \mathrm{nM}$, the probe at $250 \mathrm{nM}$, and $1 \mu \mathrm{L}$ cDNA solution. After pre-denaturation at $95^{\circ} \mathrm{C}$ for $5 \mathrm{~min}, 35$ cycles of PCR were performed at $95{ }^{\circ} \mathrm{C}$ for $15 \mathrm{sec}$ and $60{ }^{\circ} \mathrm{C}$ for $1 \mathrm{~min}$ using Rotor-Gene Q (Qiagen). The copy number of the $N$ gene in the samples was calculated using a standard curve obtained with the TA plasmid vector (Real Biotech Corporation, Banqiao City, Taiwan) containing the HCoV-OC43 N gene.

\subsection{Cell Viability Assay}

The viability of HCoV-OC43-infected Vero and MRC-5 cells was assessed by a cell-counting kit-8 (CCK-8) assay (Dojindo Laboratories, Kumamoto, Japan). Briefly, $3 \times 10^{4}$ cells/well were seeded in 24-well plates and cultured for $18 \mathrm{~h}$. The cells were washed with PBS, and mockinfected or infected with HCoV-OC43 in PBS at an MOI of 0.1 or 0.5 for $1 \mathrm{~h}$ in a $5 \% \mathrm{CO}_{2}$ incubator at $37^{\circ} \mathrm{C}$ with shaking every $15 \mathrm{~min}$. After removing the medium, the cells were washed with PBS and 2 mL of DMEM (for Vero cells) or EMEM (for MRC- 5 cells) containing $2 \%$ FBS was added to each well. After $72 \mathrm{~h}$, cell viability was determined by adding CCK-8 reagent and measuring the absorbance at $450 \mathrm{~nm}$ following the manufacturer's instructions.

\subsection{Apoptosis Assay}

Vero and MRC-5 cells $\left(2 \times 10^{5}\right.$ cells/well $)$ were seeded in 6-well plates. The cells were washed with PBS and the cells were mock-infected or infected with HCoV-OC43 in PBS at an MOI of 0.1 and 0.5 for $1 \mathrm{~h}$. After removing the medium, the cells were washed with PBS and $2 \mathrm{~mL}$ of DMEM (for Vero cells) or EMEM (for MRC-5 cells) containing 2\% FBS was added to each well and cultures for $72 \mathrm{~h}$. After removing the medium, the cells were trypsinized and washed with FACS (fluorescence-activated cell sorting) buffer (1\% FBS in PBS) followed by staining with annexin V (eBioscience, San Diego, CA, USA) for $15 \mathrm{~min}$ at room temperature in the dark. The cells were further stained with propidium iodide (PI, eBioscience) for $15 \mathrm{~min}$ and analyzed with FACSCalibur (BD Biosciences, San Jose, CA, USA). The FACS data were analyzed using Flowing Software (Turku Centre for Biotechnology, Turun Yliopisto, Finland).

\subsection{Cell Cycle Analysis}

For cell cycle analysis, Vero and MRC-5 cells $\left(2 \times 10^{5}\right.$ cells/well $)$ were seeded in 6-well plates. The cells were washed with PBS and then mock-infected or infected with HCoV-OC43 in PBS at an MOI of 0.1 and 0.5 for $1 \mathrm{~h}$. After removing the medium, the cells were washed with PBS and $2 \mathrm{~mL}$ of DMEM (for Vero cells) or EMEM (for MRC-5 cells) containing $2 \%$ FBS was added to each well and cultures for $72 \mathrm{~h}$. After removing the medium, the trypsinized cells were collected and fixed with $70 \%$ ice-cold ethanol in PBS overnight at $4{ }^{\circ} \mathrm{C}$. The cells were subsequently washed with FACS buffer and incubated with RNase (Sigma-Aldrich, St. Louis, MO, USA) for $30 \mathrm{~min}$ at $37^{\circ} \mathrm{C}$. Then the cells were stained with PI for 15 min at room temperature in the dark and analyzed with FACSCalibur 


\subsection{Western Blotting}

Vero and MRC- 5 cells $\left(2 \times 10^{5}\right.$ cells / well $)$ were seeded in 6-well plates. The cells were washed with PBS or DMEM containing $10 \%$ FBS, and then mock-infected or infected with HCoV-OC43 in PBS or DMEM containing 10\% FBS at an MOI of 0.5 for $1 \mathrm{~h}$. After removing the medium, the cells were washed with PBS and $2 \mathrm{~mL}$ of DMEM (for Vero cells) or EMEM (for MRC- 5 cells) containing $2 \%$ FBS or 10\% FBS was added to each well. At various times after infection, culture medium was removed, washed with PBS, and the cells were lysed with lysis buffer (20 mM Tris- $\mathrm{HCl}$ pH 8.0, 5 mM EDTA, $150 \mathrm{mM} \mathrm{NaCl}, 100 \mathrm{mM} \mathrm{NaF}, 2$

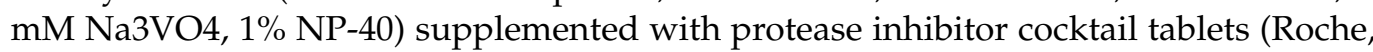
Basel, Switzerland). The cell lysates were centrifuged at $14,000 \mathrm{rpm}$ at $4{ }^{\circ} \mathrm{C}$ for $20 \mathrm{~min}$ and equal amounts of proteins were resolved on 4-12\% Bis-Tris gradient gels (Thermo Fisher Scientific) and transferred by electrophoresis onto nitrocellulose membranes. Membranes were blocked with $3 \%$ bovine serum albumin, incubated with primary antibodies overnight at $4{ }^{\circ} \mathrm{C}$, and then incubated with horseradish peroxidase (HRP)-conjugated secondary antibodies. The protein bands were detected using an enhanced chemiluminescence reagent (Thermo Fisher Scientific) and visualized with ChemiDoc (Bio-Rad, Hercules, California, USA). Antibodies against poly-ADP ribose polymerase (PARP, Catalog No. 9542S), cleaved caspase-3 (Catalog No. 9661S), c-Myc (Catalog No. 5605S), cyclin D1 (Catalog No. 2978S), phospho-STAT1 (Tyr-701) (pSTAT1, Catalog No. 9167S), STAT1 (Catalog No. 14994S), phospho-STAT3 (Tyr-705) (pSTAT3, Catalog No. 9145S), STAT3 (Catalog No. 12640S), phospho-IкB $\alpha$ (pIкB $\alpha$ Catalog No. 9246S) and IкB $\alpha$ (Catalog No. 4814S) were purchased from Cell Signaling Technology (Danvers, MA, USA). Antibodies against HCoV-OC43 N (Catalog No. LS-C79764) and S protein (Catalog No. LS-C371066) were obtained from LifeSpan BioSciences (Seattle, WA, USA). Antibody for $\beta$-actin was purchased from Sigma-Aldrich.

\subsection{Interferon- $\alpha$ Treatment}

Vero cells $\left(2 \times 10^{5}\right.$ cells /well) were seeded in 6-well plates. The cells were washed with PBS and then mock-infected or infected with HCoV-OC43 in PBS at an MOI of 0.5 for $1 \mathrm{~h}$. After removing the medium, the cells were washed with PBS, and then $2 \mathrm{~mL}$ of DMEM containing $2 \%$ FBS and interferon- $\alpha-2 a$ (IFN- $\alpha-2 a, 1000 \mathrm{IU} / \mathrm{mL}$, Sino Biological (Cat. No. 13833-HNAY, Vienna, Austria) was added to each well. At various times after infection, culture medium was harvested and viral titer was measured using plaque assay. The cells were washed with PBS, and the cells were lysed with lysis buffer for western blotting.

\subsection{Inhibition of Apoptosis}

Vero and MRC-5 cells $\left(2 \times 10^{5}\right.$ cells/well) were seeded in 6-well plates and pretreated with Z-VAD-FMK (R\&D Systems, Minneapolis, USA) or DMSO for $1 \mathrm{~h}$ before HCoV-OC43 infection. The cells were washed with PBS and infected with HCoV-OC43 in PBS at an MOI of 0.1 for $1 \mathrm{~h}$. After infection, Vero and MRC- 5 cells were replenished with DMEM containing $2 \%$ FBS or EMEM containing $2 \%$ FBS, respectively. Supernatants containing viruses from Vero and MRC-5 cells were harvested at $72 \mathrm{~h}$ and virus titers were determined by a plaque formation assay. The cell lysates were harvested at $72 \mathrm{~h}$ and analyzed by western blot.

\subsection{Statistical Analysis}

Results are shown as the mean \pm standard deviation. Differences between the samples were analyzed using an unpaired, two-tailed nonparametric $t$-test of significance (Instat; GraphPad Inc., San Diego, CA, USA). $p$-values $<0.05$ were considered statistically significant.

\section{Results}

\subsection{HCoV-OC43 Replication and Induction of Apoptosis in Vero and MRC-5 Cells}

Viral infection processes can differ depending on cell type; therefore, we used two susceptible cell lines, Vero and MRC-5. Viral infection processes were performed in PBS and 
then cultured with DMEM (for Vero cells) or EMEM (for MRC-5 cells) containing 2\% FBS. To determine the patterns of viral replication and the host response to infection, we used plaque assays (Figure 1A) and quantitative real-time PCR (Figure 1B) to measure HCoVOC43 in cell culture supernatants harvested at several times after inoculation of cells with $\mathrm{HCoV}-\mathrm{OC} 43$ at various MOIs. The number of viruses increased in an MOI-dependent and time-dependent manner in Vero and MRC-5 cells (Figure 1). We also performed infection in medium containing $10 \%$ FBS and then determined the patterns of viral replication in Vero cells (Figure S1). Compared to the results in 2\% FBS condition, virus replication was markedly reduced at $24 \mathrm{~h}$ and $48 \mathrm{~h}$ by more than $90 \%$ irrespective of infected virus MOI in $10 \%$ FBS condition. Virus production was similar in both conditions only at $72 \mathrm{~h}$ after infection with $0.5 \mathrm{MOI}$ of $\mathrm{HCoV}-\mathrm{OC} 43$. Therefore, we infected and cultured the cells in medium containing $2 \%$ FBS for most of the experiments and used $10 \%$ FBS condition with an MOI of 0.5 only for control experiments.
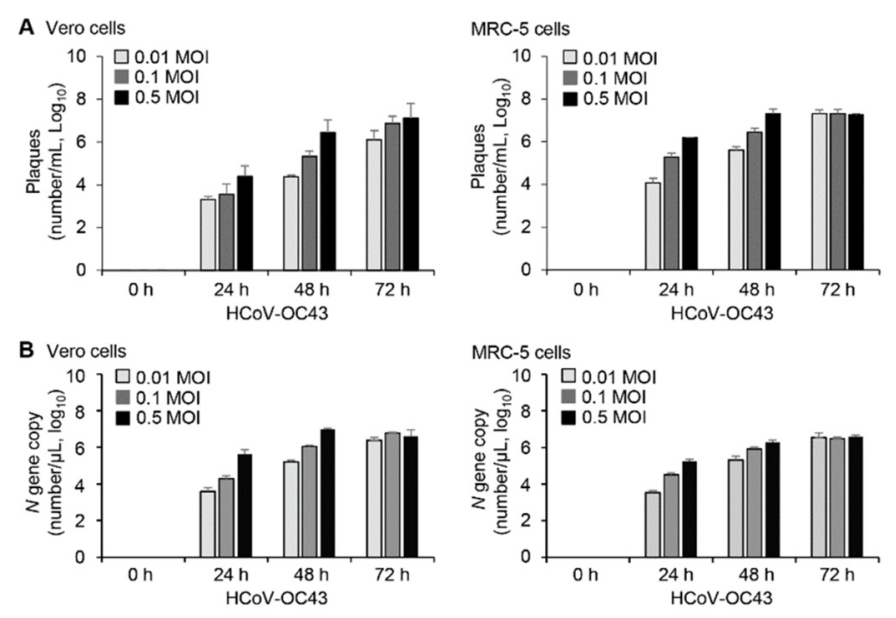

Figure 1. Multiplication of HCoV-OC43 in Vero and MRC-5 cells. Vero and MRC-5 cells $\left(2 \times 10^{5}\right.$ cells/well) were infected with HCoV-OC43 in PBS at an MOI of $0.01,0.1$, or 0.5 for $1 \mathrm{~h}(n=3)$. At the indicated times after infection, supernatants were collected and analyzed. (A) Virus titers in the supernatants were determined by plaque assays. (B) Viral replication was quantified by RT-qPCR analysis for the $\mathrm{HCoV}-\mathrm{OC} 43$ nucleocapsid $(N)$ gene in the supernatants. Copy numbers of the $N$ gene in $1 \mu \mathrm{L}$ of the cDNA samples were calculated using a standard curve obtained with cDNA of the $N$ gene.

Since virus-induced apoptosis may benefit viral reproduction [21,27], we assessed the cytotoxic effect of HCoV-OC43 infection in Vero and MRC-5 cells and found that HCoVOC43 infection at an MOI of 0.1 or 0.5 significantly reduced viability of Vero and MRC-5 cells in comparison to mock-infected control cells (Figure 2A). To determine whether the decrease in cell viability was associated with $\mathrm{HCoV}-\mathrm{OC} 43$-mediated apoptosis, we measured the exposed phosphatidylserine on the cell membrane using annexin V and PI staining at $72 \mathrm{~h}$ post-infection. There was an increase in apoptotic cells after infection with $\mathrm{HCoV}-\mathrm{OC} 43$ compared to the mock-infection control (Figure 2B and Figure S2A). Vero cells showed higher percentage of dead or necrotic cell population than MRC-5 cells after $\mathrm{HCoV-OC} 43$ infection. When we infected the cells with HCoV-OC43 at an MOI of $0.5,1$ or 2 and analyzed at $24 \mathrm{~h}$ or $48 \mathrm{~h}$ after infection, there was no prominent apoptosis in Vero cells, but necrotic cell population slightly increased after $\mathrm{HCoV}-\mathrm{OC} 43$ infection compared to mock control (Figure S3A). There was no prominent apoptosis in MRC-5 cells, either (Figure S3B). Therefore, apoptosis seems to occur only at later time points.

Differently from cell viability, most of the analyzed cells were living cells and the apoptotic cell population were comparatively small, only up to a maximum of about $14 \%$ (Figure 2B). This can result partly from the difference in assay principles. While cell viability measured with CCK-8 reagent represents enzyme activity of cellular dehydrogenase rather 
than living cell numbers, readouts of apoptosis assay obtained by FACS represent cell numbers of each population. It is also necessary to consider that the apoptosis assay procedure excludes suspended dead/necrotic cells and debris which are lost during washing steps. There is another possibility that $\mathrm{HCoV}-43$ infection also induces other types of cell death including necroptosis, another form of programmed cell death, in Vero cells and MRC-5 cells as described in neuronal cells $[28,29]$. As we are interested in STAT signaling and apoptosis, we focused on apoptosis in this study.
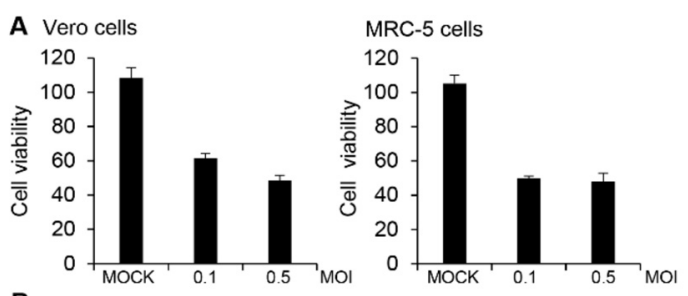

$$
\text { B }
$$

Vero cells
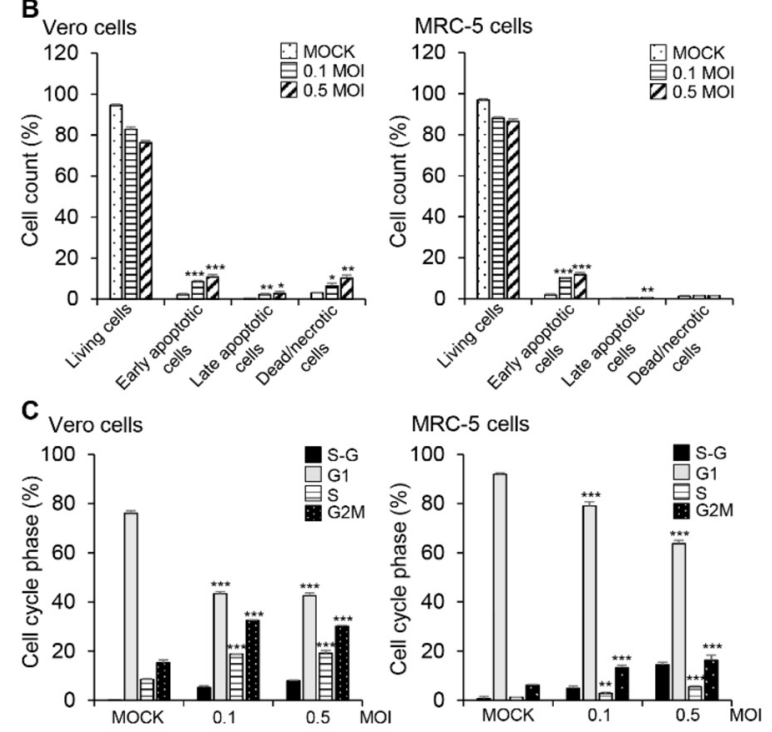

Figure 2. HCoV-OC43 infection triggers apoptosis in Vero and MRC-5 cells. Vero and MRC-5 cells were mock-infected with PBS or infected with HCoV-OC43 in PBS at an MOI of 0.1 or 0.5 for $1 \mathrm{~h}$ $(n=3)$. The medium was replaced with DMEM containing $2 \%$ FBS or EMEM containing $2 \%$ FBS for Vero and MRC-5 cells, respectively. (A) Cell viability was determined with CCK-8 assays at $72 \mathrm{~h}$ post-infection. (B) Cells harvested at $72 \mathrm{~h}$ post-infection were stained with annexin V and PI and subjected to FACS analysis. The bar graphs show percentages of cells with indicated properties. (C) Cells were stained with PI at $72 \mathrm{~h}$ post-infection and the distribution of cells at various phases of the cell cycle was determined by flow cytometry. Each bar graph represents the percentage of cells in each phase of cell cycle. These results are representative of three independent experiments. ${ }^{*} p<0.05$, ** $p<0.01,{ }^{* * *} p<0.001$.

Many viruses block cell cycle progression to support viral replication [30]. Therefore, we evaluated the effect of $\mathrm{HCoV}-\mathrm{OC} 43$ infection on host cell cycle progression and found that a substantial proportion of Vero and MRC -5 cells were found in the $S$ and $G_{2} / M$ phases of the cell cycle after infection with $\mathrm{HCoV}-\mathrm{OC} 43$ (Figure 2C and Figure S2B). Moreover, infection with $\mathrm{HCoV}-\mathrm{OC} 43$ resulted in an increase of cells at the sub- $\mathrm{G}_{1}$ phase in both cell lines even though cell cycle distribution patterns are different in the two cells, further suggesting apoptosis (Figure 2C and Figure S2B). Taken together, these data indicate that $\mathrm{HCoV}-\mathrm{OC} 43$ infection induced apoptosis and the arrest of cells in the $S$ and $\mathrm{G}_{2} / \mathrm{M}$ phases of the cycle in Vero and MRC-5 cells. 


\subsection{Effects of HCoV-OC43 Infection on Apoptotic and Cell Proliferation Marker Expression}

Caspases, cysteine-aspartic proteases, are important mediators of apoptosis [31,32], and some viruses use host cell caspases to assist in their replication [33]. PARP is one of the cellular substrates of caspase and cleaved PARP is a hallmark of apoptosis [34]. Therefore, we mock-infected or infected Vero and MRC- 5 cells with HCoV-OC43 at an MOI of 0.5 at various time intervals and measured apoptotic and cell proliferation markers using western blots. The amount of cleaved PARP and cleaved caspase-3 increased significantly $72 \mathrm{~h}$ after HCoV-OC43 infection in Vero and MRC-5 cells, whereas no differences were observed in the mock-infected cells (Figure 3A,B). We also found that cyclin D1, which is a marker for the proliferation and growth of cells [35], decreased in Vero and MRC-5 cells in response to virus infection compared to mock-infected cells (Figure 3A,B and Figure $\mathrm{S} 4 \mathrm{~A}, \mathrm{~B})$. In contrast, expression of c-Myc, another proliferation marker [36], decreased after $\mathrm{HCoV-OC43}$ infection as well as mock-infection in Vero cells and MRC-5 cells. Therefore, it is likely that the culture condition rather than the virus infection resulted in the decrease of c-Myc (Figure 3A,B and Figure S4A,B). Thus, these data demonstrate that induction of apoptosis was associated with reduced cyclin D1 expression and activation of caspase-3 and PARP in HCoV-OC43-infected Vero and MRC-5 cells.
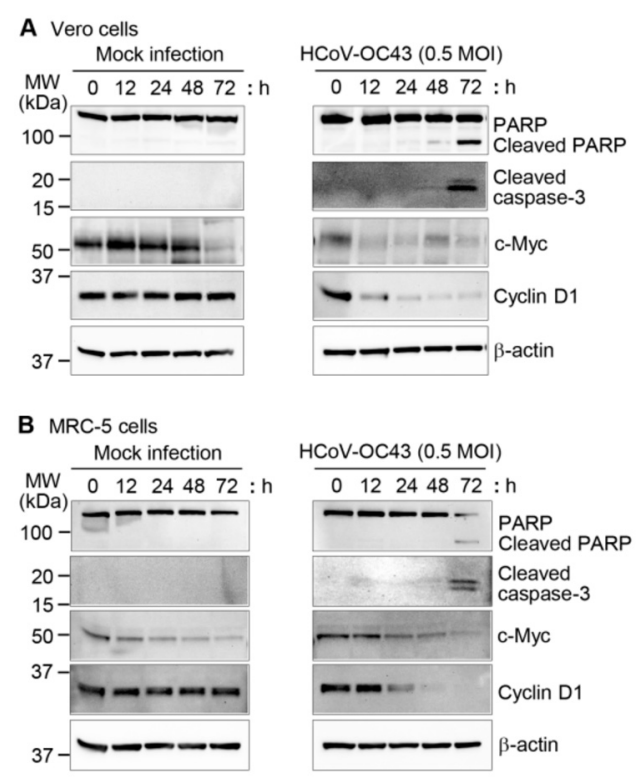

Figure 3. HCoV-OC43 infection affects apoptotic and growth-related marker expression in Vero and MRC-5 cells. Vero (A) and MRC-5 (B) cells were mock-infected with PBS or with HCoV-OC43 in PBS at an MOI of 0.5 for $1 \mathrm{~h}$. After washing the cells, the medium was replaced with DMEM or EMEM containing $2 \%$ FBS for Vero and MRC-5, respectively. After removing the culture medium, cells were harvested at the indicated times and western blots were performed on cell lysates using antibodies to PARP, cleaved caspase-3, c-Myc, and cyclin D1. $\beta$-actin antibody was used to verify equal protein loading. The protein band intensities were measured and relative band intensities are shown as a graph in Figure S4. These results are representative of three independent experiments.

\subsection{HCoV-OC43 Infection Decreased Phosphorylation of STAT1 and STAT3 in Vero and MRC-5 Cells}

Since STAT1 and STAT3 are involved in apoptosis [37-39] and viral replication [40-42], we measured the expression of phospho-STAT1 and phospho-STAT3 in HCoV-OC43infected Vero and MRC-5 cells. Vero and MRC- 5 cells were mock-infected or HCoV-OC43 infected and harvested at different times. In Vero cells, STAT1 and STAT3 phosphorylation level similarly increased until $24 \mathrm{~h}$ culture in medium containing $2 \%$ FBS after mock-infection and HCoV-OC43 infection. However, STAT1 and STAT3 phosphorylation decreased sharply by $48 \mathrm{~h}$ only after $\mathrm{HCoV}-\mathrm{OC} 43$ infection (Figure $4 \mathrm{~A}$ right panel and Fig- 
ure S5A). In the mock-infected Vero cells, high levels of phosphoproteins persisted until the last time point (Figure 4A left panel and Figure S5A). When we checked phosphorylation levels of STAT1 and STAT3 at $6 \mathrm{~h}$ after infection in Vero cells, there was still no prominent effect of HCoV-OC43 infection (Figure S6). It is likely that phosphorylation was induced by the addition of serum-containing medium rather than by virus infection, since mock infection as well as HCoV-OC43 infection was carried out in PBS without serum for $1 \mathrm{~h}$ after washing the cells with PBS. To confirm this issue, we performed mock infection in medium containing 10\% FBS after washing the cells with the same medium. STAT1 and STAT3 phosphorylation occurred consistently in Vero cells during the mock infection culture as we expected (Figure 4B). When Vero cells were infected with HCoV-OC43 in medium containing $10 \%$ FBS, STAT1 and STAT3 phosphorylation decreased sharply by $48 \mathrm{~h}$ as was found in $2 \%$ FBS condition (Figure $4 \mathrm{~B}$ right panel). In contrast, the basal phosphorylation levels of STAT1 and STAT3 in MRC- 5 cells in 2\% FBS condition were high, and the addition of $10 \%$ FBS containing medium did not affect phosphorylation (Figure 4C,D and Figure S5B). Considering that Vero cells are defective in the type I interferon genes [43], IFN signaling might be related to the higher STAT phosphorylation levels in MRC-5 cells. However, HCoV-OC43 infection reduced the phosphorylation levels at later time points, similar to Vero cells (Figure $4 \mathrm{C}$ right panel and Figure S5B). Because the NF- $\mathrm{KB}$ signaling pathway is activated by several viruses, we measured I $\mathrm{B} \alpha$ phosphorylation and degradation, but no significant changes were observed in Vero and MRC-5 cells with or without HCoV-OC43 infection. These results indicate that $\mathrm{HCoV}-\mathrm{OC} 43$ infection specifically reduced STAT1 and STAT3 phosphorylation, which could induce apoptosis in the infected cells.

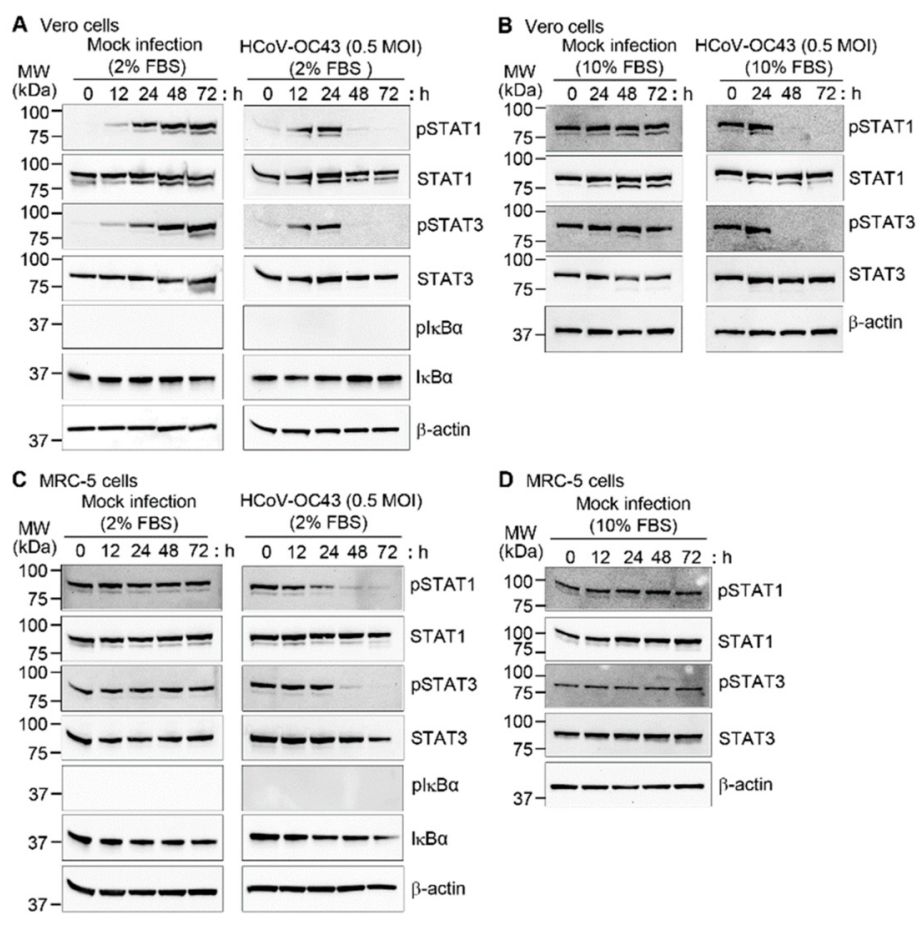

Figure 4. Effect of HCoV-OC43 infection on phosphorylation of STAT1, STAT3, and IкB $\alpha$. Vero (A,B) and MRC-5 (C,D) cells were mock-infected with PBS or infected with HCoV-OC43 in PBS or 10\% FBS at an MOI of 0.5 for $1 \mathrm{~h}$. The medium was replenished with DMEM or EMEM containing 2\% FBS or $10 \%$ FBS for Vero and MRC- 5 cells, respectively, and the cells were grown for the indicated times. At the indicated times after infection, cell lysates were examined by western blotting with antibodies against pSTAT1, STAT1, pSTAT3, STAT3, $\operatorname{pI\kappa B} \alpha$, and $\operatorname{I\kappa B} \alpha$. $\beta$-actin antibody was used to verify equal protein loading. The protein band intensities of pSTAT1 and pSTAT3 were measured and relative band intensities are shown as a graph in Figure S5. These results are representative of three independent experiments. 


\subsection{Suppression of Apoptosis and Reduction of the Viral Load by Caspase Inhibition}

To determine whether the apoptotic changes in HCoV-OC43-infected cells were caspase-dependent, we used z-VAD-FMK, an inhibitor of various caspases, including caspase-3 [44]. Vero and MRC-5 cells treated with z-VAD-FMK at $10 \mu \mathrm{M}$ and $50 \mu \mathrm{M}$ and then assayed using CCK-8 showed no evidence of cytotoxicity (Figure 5A). To determine whether z-VAD-FMK could inhibit HCoV-OC43-induced apoptosis in Vero and MRC-5 cells, we measured the cleavage of caspase- 3 and PARP protein. Treatment of HCoV-OC43infected Vero and MRC- 5 cells with z-VAD-FMK reduced the amount of cleaved caspase-3 and blocked cleavage of PARP (Figure 5B left panel). To measure virus production, the expression of $\mathrm{HCoV}-\mathrm{OC} 43 \mathrm{~N}$ and $\mathrm{S}$ proteins was determined in the presence and absence of z-VAD-FMK by western blot analysis. z-VAD-FMK significantly reduced the levels of viral $\mathrm{N}$ and $\mathrm{S}$ proteins in the virus-infected cells (Figure $5 \mathrm{~B}$ left panel). However, $\mathrm{z}$-VAD-FMK did not affect STAT1 and STAT3 phosphorylation status suggesting that apoptosis can be a downstream event of STAT dephosphorylation (Figure 5B right panel). Plaque formation assay showed that $\mathrm{HCoV}-\mathrm{OC} 43$ replication was reduced in the presence of z-VAD-FMK in Vero cells and MRC-5 cells (Figure 5C) by about $1 \log$. More specifically, virus titer was reduced by $81.9 \%$ for Vero cells and $82.3 \%$ for MRC- 5 cells in the presence of z-VAD-FMK. These results suggest that $\mathrm{HCoV}-\mathrm{OC} 43$-induced apoptosis contributes to virus replication in Vero and MRC- 5 cells.
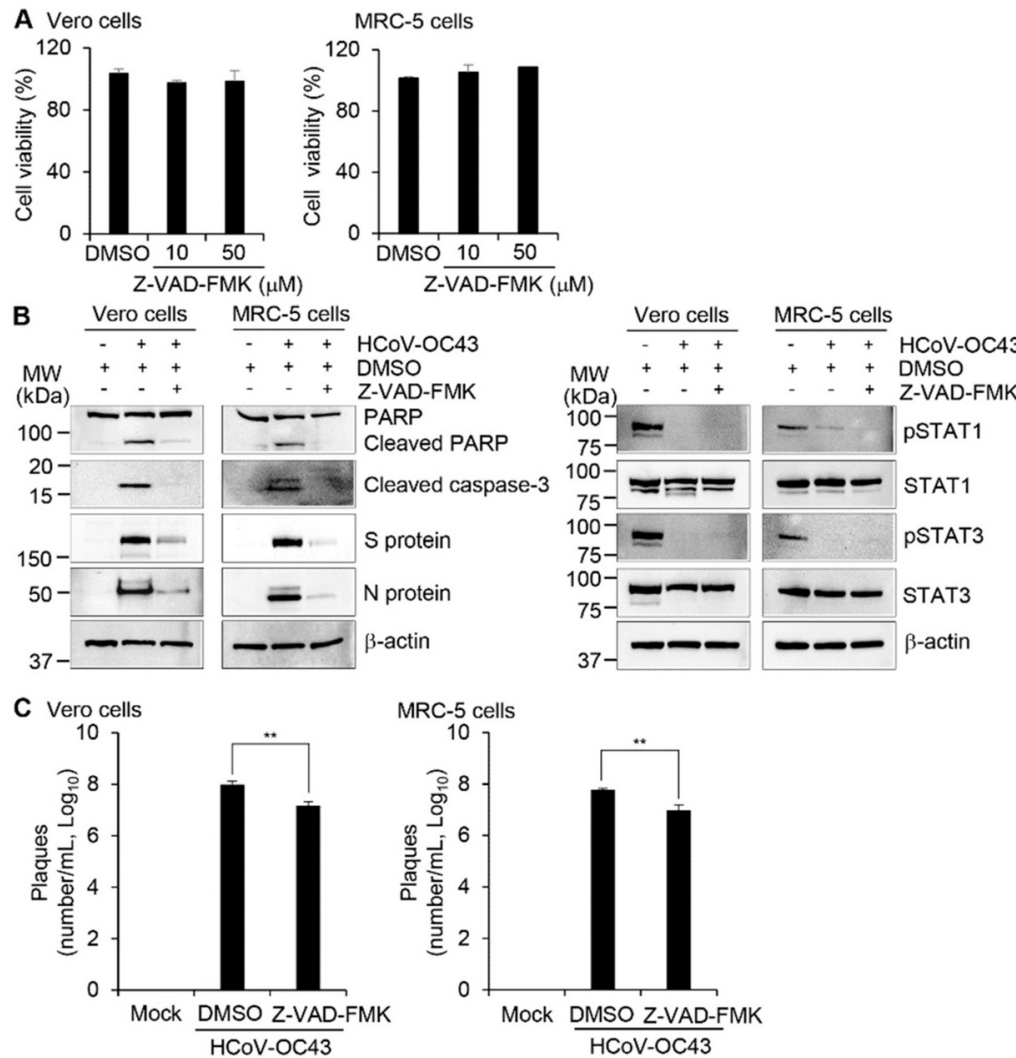

Figure 5. Treatment with a caspase inhibitor attenuates HCoV-OC43 replication. (A) Vero and MRC- 5 cells were treated with DMSO or the indicated concentration of Z-VAD-FMK for $72 \mathrm{~h}$. Cell viability was determined by CCK-8 assays. $(\mathbf{B}, \mathbf{C})$ Vero and MRC- 5 cells were treated with DMSO or Z-VAD-FMK $(50 \mu \mathrm{M})$ for $1 \mathrm{~h}$, followed by mock infection or HCoV-OC43 infection at an MOI of 0.1. (B) The lysates of cells harvested $72 \mathrm{~h}$ after infection were examined by western blotting using antibodies against PARP, cleaved caspase-3, and HCoV-OC43 N and S proteins (left) and pSTAT1, STAT1, pSTAT3, STAT3 (right). $\beta$-actin antibody was used to verify equal protein loading. (C) Virus titers from supernatants collected at $72 \mathrm{~h}$ post-infection were determined by plaque assays. ${ }^{* *} p<0.01$. 


\subsection{Activation of STAT 1 and STAT3 and Reduction of the Viral Load by Interferon- $\alpha$}

Interferon- $\alpha-2 \mathrm{a}$ (IFN- $\alpha-2 \mathrm{a})$ is one of type I interferons which are known to induce activation of STATs including STAT1 and STAT3 [45]. As we found that STAT1 and STAT3 dephosphorylation is associated with apoptosis and apoptosis contributes to virus replication, we investigated the effects of IFN- $\alpha-2 \mathrm{a}$ after $\mathrm{HCoV}-\mathrm{OC} 43$ infection in Vero cells (Figure 6A and Figure S7). Treatment with $1000 \mathrm{IU} / \mathrm{mL}$ of IFN- $\alpha-2 \mathrm{a}$ increased STAT1 and STAT3 phosphorylation in mock-infected cells as we expected (Figure 6A left panel). IFN- $\alpha$-2a clearly delayed reduction of STAT1 phosphorylation and slightly suppressed STAT3 phosphorylation in response to HCoV-OC43 infection at an MOI of 0.5 (Figure 6A right panel and Figure S7). Accordingly, virus production was reduced in the presence of IFN- $\alpha$-2a by $54.3 \%$ ( $0.34 \log$ decrease) and $46.3 \%$ ( $0.27 \log$ decrease) at $24 \mathrm{~h}$ and $48 \mathrm{~h}$ after infection, respectively, compared to the results in the absence of IFN- $\alpha-2 a$. Considering that we used $0.5 \mathrm{MOI}$ of $\mathrm{HCoV}-\mathrm{OC} 43$, this outcome is consistent with the previous report regarding the effect of IFN- $\alpha-2 \mathrm{~b}$ on SARS-CoV replication in Vero E6 cells; treatment with $1000 \mathrm{IU} / \mathrm{mL}$ of IFN- $\alpha-2 \mathrm{~b}$ reduced about $0.5 \log$ decrease in virus titers at $72 \mathrm{~h}$ after infection with 0.001 MOI of SARS-CoV [46]. These results suggest that IFN- $\alpha$-2a-induced increase of STAT1 and STAT3 phosphorylation contributes to the suppressive effect of IFN- $\alpha-2 a$ on virus replication in Vero cells.

A Vero cells

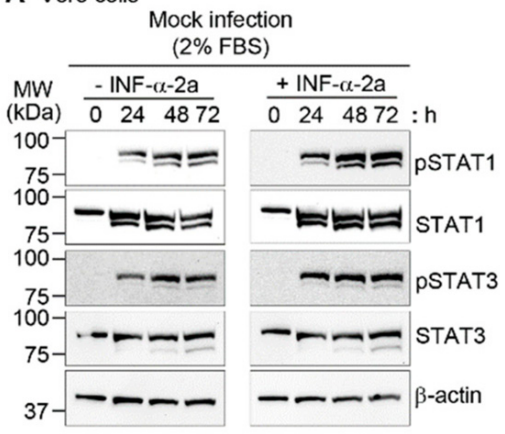

B Vero cells

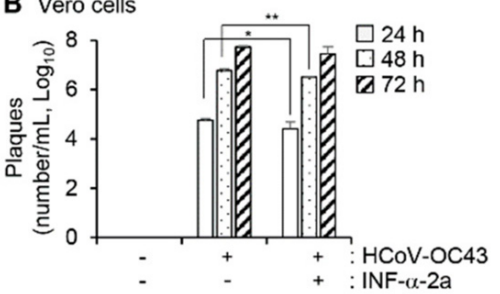

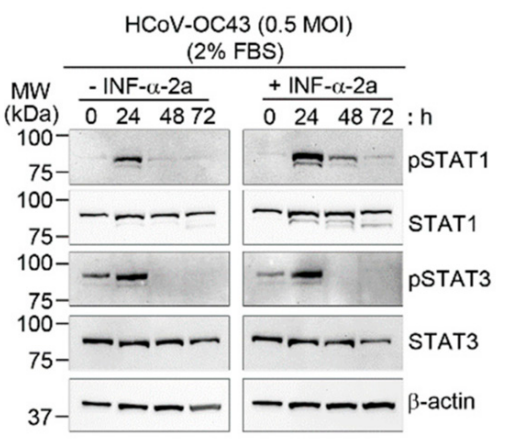

Figure 6. Effect of IFN- $\alpha-2 \mathrm{a}$ on STAT1 and STAT3 phosphorylation and viral replication. (A) Vero cells were mock-infected with PBS or infected with HCoV-OC43 in PBS at an MOI of 0.5 for $1 \mathrm{~h}$. The medium was replenished with DMEM containing 2\% FBS with or without $1000 \mathrm{IU} / \mathrm{mL}$ of IFN- $\alpha-2 \mathrm{a}$. At the indicated times after infection, cell lysates were examined by western blotting with antibodies against pSTAT1, STAT1, pSTAT3, and STAT3. $\beta$-actin antibody was used to verify equal protein loading. The protein band intensities of PSTAT1 and pSTAT3 were measured and relative band intensities are shown as a graph in Figure S7. (B) Virus titers from the cell culture supernatants collected at the indicated times after infection were determined by plaque assays. ${ }^{*} p<0.05,{ }^{* *} p<0.01$.

\section{Discussion}

Programmed cell death or apoptosis is an essential host cell response to viral infection $[47,48]$. In order to survive and propagate, many viruses have evolved methods to inhibit apoptosis and promote their replication [49,50]. In contrast, other viruses take advantage of host cell apoptosis to escape the host immune system. Moreover, apoptosis of infected cells facilitates the release of progeny viruses and their transmission to other cells. This response is also important for the pathogenesis of the virus, leading to cell 
death and tissue damage $[27,48]$. Several coronaviruses such as swine acute diarrhea syndrome coronavirus (SADS-CoV), porcine epidemic diarrhea virus (PEDV), porcine delta coronavirus (PDCoV), avian infectious bronchitis virus (IBV), and mouse hepatitis virus (MHV) have various strategies to modulate apoptotic pathways in different cell lines to promote viral replication and propagation [51]. However, little information is available on HCoV-OC43-induced apoptosis or the underlying cellular mechanism in lung cells [18]. In this study, we determined the mechanism of HCoV-OC43-induced apoptosis in Vero and MRC- 5 cells that contributes to viral replication.

Cell death is a common outcome of virus infection and replication [52], and we show that $\mathrm{HCoV}-\mathrm{OC} 43$ infection decreased cell viability and induced apoptosis in Vero and MRC- 5 cells. Considering that the apoptotic cell population is relatively small compared to the decreased cell viability and appears only at late time points $(72 \mathrm{~h})$ after virus infection, it is likely that HCoV-OC43 infection majorly induces other types of cell death and apoptosis is an additional form of cell death occurring after several cellular and viral events. It should be noted that large amounts of viral particles are produced at 24 or $48 \mathrm{~h}$ after infection without apoptosis. Therefore, cell death such as necrosis, unregulated cell death, or necroptosis seem to be the major forms of cell death. In neuronal cells, HCoV-OC43 induces necroptosis $[28,29]$. HCoV-OC43 induces caspase activation in neuronal cells, but HCoV-OC43-induced cell death is dependent on Cyclophilin D rather than caspase [28]. Furthermore, the regulated cell death in neuronal cells is dependent on Receptor-Interacting Protein Kinase 1 (RIP1) and Mixed Lineage Kinase Domain-Like (MLKL) [29] which are implicated in necroptosis [23]. As downregulation of RIP1 decreased cell death and increased production of infectious viral particles in neuronal cells, necroptosis seems to limit replication of HCoV-OC43 [29]. Therefore, detailed analysis on the cell death types after $\mathrm{HCoV}-\mathrm{OC} 43$ infection and their contribution to virus production in Vero and MRC-5 cells remains to be investigated.

The sub-G1 phase was elevated in HCoV-OC43-infected Vero and MRC-5 cells, and $\mathrm{S}$ and G2/M phase cells accumulated. Previous studies have shown that cell cycle arrest in $\mathrm{S}$ and $\mathrm{G} 2 / \mathrm{M}$ phases by virus infection promotes viral replication [53,54]. Coronaviruses such as SADS-CoV, canine $\mathrm{CoV}$, and IBV induce apoptosis via activation of the caspase cascade $[16,55,56]$. Similarly, $\mathrm{HCoV}-\mathrm{OC} 43$ infection activated caspase- 3 and induced cleavage of one of the main cellular substrates of caspases, PARP, indicating the involvement of caspase in HCoV-OC43-induced apoptosis. Accordingly, the expression of proliferation-related cyclin D1 was decreased. In addition, HCoV-OC43 infection reduced phosphorylation of STAT1 and STAT3 in both Vero and MRC-5 cells. Suppression of STAT1 and STAT3 is associated with the induction of apoptosis [37-39] and virus production [40-42]. Dephosphorylation or degradation of STAT3 through cellular or viral factors are associated with apoptosis of host cells infected with influenza A virus, hepatitis E virus, and SARS-CoV $[41,57,58]$. However, the underlying mechanism of STAT1 and STAT3 dephosphorylation in response to $\mathrm{HCoV}-\mathrm{OC} 43$ infection is to be determined.

As Vero cells cannot produce type I interferons, Vero cells lack competent interferon signaling in response to virus infection. Therefore, we treated Vero cells with IFN- $\alpha-2 a$ as an activator of STATs and examined the effect on STAT signaling and virus production. IFN- $\alpha-2 \mathrm{a}$ increased basal levels of STAT1 and STAT3 phosphorylation as we expected. Furthermore, IFN- $\alpha-2 \mathrm{a}$ alleviated dephosphorylation of STAT1 and STAT3 upon HCoV-OC43 infection and reduced virus production. Therefore, these results support our suggestion that STAT dephosphorylation is associated with host cell apoptosis and $\mathrm{HCoV-OC43}$ virus replication. We recently found that Vero and Calu-3 cells are susceptible to SARS-CoV-2; however, the two cell types show differences in signaling after infection with respect to STAT activation and apoptosis [59]. In Vero cells, STAT1 and STAT3 phosphorylation disappeared after SARS-CoV-2 infection, as we showed here for HCoV-OC43-infected Vero and MRC-5 cells. In contrast, SARS-CoV-2-infection induced persistent STAT1 and STAT3 phosphorylation in Calu-3 cells. Consistent with the activation status of STATs, apoptotic signals were detected in Vero cells but not in Calu-3 cells after SARS-CoV-2-infection, and 
higher virus production was found in Vero cells. Since Calu-3 cells are not susceptible to $\mathrm{HCoV}-\mathrm{OC} 43$, we cannot determine whether this differential signaling depends on virus type or cell type.

z-VAD-FMK, a pan-caspase inhibitor, suppresses the inhibition of virus-induced apoptosis and viral replication in Sindbis virus (SV)- and SADS-CoV-infected cells $[16,60]$. Pretreatment with z-VAD-FMK significantly decreased the levels of cleaved caspase- 3 and cleaved PARP protein in HCoV-OC43-infected Vero and MRC-5 cells and reduced viral production, as determined by $\mathrm{HCoV}-\mathrm{OC} 43 \mathrm{~N}$ and $\mathrm{S}$ protein expression and by plaque assays. These data suggest that activation of caspase-3 is required for HCoV-OC43-mediated apoptosis and viral replication in Vero and MRC- 5 cells. However, the effect of z-VAD-FMK on virus replication was marginal compared to the total virus titers even though it was significant. This can be partly explained from the limited efficacy of the inhibitor. We pretreated the cells with z-VAD-FMK for only $1 \mathrm{~h}$, washed, and evaluated the effect on virus replication at $72 \mathrm{~h}$ after infection. Furthermore, the viral titers at $72 \mathrm{~h}$ represent accumulated ones continuously produced for $72 \mathrm{~h}$ after infection in the presence or absence of the caspase inhibitor. It is also necessary to consider that the caspase- 3 activation and apoptosis-associated events occurred only at the later times. Collectively, our results suggest that $\mathrm{HCoV}-\mathrm{OC} 43$ infection induced suppression of STAT signaling and apoptosis to promote viral replication in Vero and MRC-5 cells at least in part.

\section{Conclusions}

HCoV-OC43-mediated dephosphorylation of STAT1 and STAT3 and induction of apoptosis may serve as a mechanism to promote the dissemination of viral progeny in Vero and MRC- 5 cells. Viral replication and spread could be limited by treatment with caspase inhibitors, affording the host cell some protection.

Supplementary Materials: The following are available online at https:/ /www.mdpi.com/article/ 10.3390/v13112199/s1, Figure S1: Multiplication of HCoV-OC43 in Vero cells, Figure S2: (Corresponding to Figure 2A,B) HCoV-OC43 infection triggers apoptosis in Vero and MRC-5 cells, Figure S3: Effect of HCoV-OC43 infection at high MOI on apoptosis in Vero and MRC-5 cells, Figure S4: (Corresponding to Figure 3) Analysis of relative band densities from western blotting, Figure S5: (Corresponding to Figure 4) Analysis of relative band densities from western blotting, Figure S6: STAT1 and STAT3 phosphorylation at early HCoV-OC43 infection in Vero cells, Figure S7: (Corresponding to Figure 6A) Analysis of relative band densities from western blotting.

Author Contributions: H.-J.K. and Y.L. conceived of the project and designed the study. H.-J.K., Y.L. and S.M. wrote the manuscript. S.M., M.K. (Mijeong Kang), J.K., D.K., S.P., M.K. (Minyoung Kim) and K.B. carried out the experiments. H.-J.K., S.M., M.K. (Mijeong Kang), J.K. and Y.L analyzed the data. All authors have read and agreed to the published version of the manuscript.

Funding: This research was supported by grants from the National Research Foundation (NRF2020M3A9I2107294) funded by the Ministry of Science and ICT in the Republic of Korea.

Data Availability Statement: All data needed to evaluate the conclusions in this manuscript have been included. Additional data may be requested from the authors.

Acknowledgments: We thank Ki-Jun Song (Korea Bank for Pathogenic Viruses, College of Medicine, Korea University, Seoul, Korea) for supplying HCoV-OC43 (KBPV-VR-8).

Conflicts of Interest: The authors declare that the research was conducted in the absence of any commercial or financial relationships that could be construed as a potential conflict of interest. 


$\begin{array}{ll}\text { Abbreviations } \\ \text { CCK-8 } & \text { Cell-counting kit-8 } \\ \text { CoVs } & \text { Coronaviruses } \\ \text { DMEM } & \text { Dulbecco's modified Eagle's medium } \\ \text { DMSO } & \text { Dimethyl Sulfoxide } \\ \text { EMEM } & \text { Eagle's Minimum Essential Medium } \\ \text { FACS } & \text { Fluorescence-activated cell sorting } \\ \text { FBS } & \text { Fetal bovine serum } \\ \text { HCoVs } & \text { Human coronaviruses } \\ \text { HCoV-OC43 } & \text { Human coronavirus OC43 } \\ \text { HRP } & \text { Horseradish peroxidase } \\ \text { IFN } & \text { Interferon } \\ \text { IkB } & \text { Inhibitory kappa B } \\ \text { MERS-CoV } & \text { Middle East respiratory syndrome coronavirus } \\ \text { MOI } & \text { Multiplicity of infection } \\ \text { N } & \text { Nucleocapsid } \\ \text { NF-kB } & \text { Nuclear factor kappa-light-chain-enhancer of activated B cells } \\ \text { PARP } & \text { Poly-ADP ribose polymerase } \\ \text { PBS } & \text { Phosphate-buffered saline } \\ \text { PCR } & \text { Polymerase chain reaction } \\ \text { PI } & \text { Propidium iodide } \\ \text { RT-qPCR } & \text { Reverse transcriptase-quantitative PCR } \\ \text { S } & \text { Spike } \\ \text { SARS-CoV } & \text { Severe acute respiratory syndrome coronavirus } \\ \text { STAT1 } & \text { Signal transducer and activator of transcription 1 } \\ \text { STAT3 } & \text { Signal transducer and activator of transcription 3 } \\ \end{array}$

\section{References}

1. Zhao, X.; Ding, Y.; Du, J.; Fan, Y. 2020 update on human coronaviruses: One health, one world. Med. Nov. Technol. Devices 2020, 8, 100043. [CrossRef]

2. Liu, D.X.; Liang, J.Q.; Fung, T.S. Human Coronavirus-229E, -OC43, -NL63, and -HKU1 (Coronaviridae). In Encyclopedia of Virology, 4th ed.; Bamford, D.H., Zuckerman, M., Eds.; Academic Press: Cambridge, MA, USA, 2021; Volume 2, pp. $428-440$.

3. Jacomy, H.; Fragoso, G.; Almazan, G.; Mushynski, W.E.; Talbot, P.J. Human coronavirus OC43 infection induces chronic encephalitis leading to disabilities in BALB/C mice. Virology 2006, 349, 335-346. [CrossRef]

4. Drosten, C.; Günther, S.; Preiser, W.; van der Werf, S.; Brodt, H.R.; Becker, S.; Rabenau, H.; Panning, M.; Kolesnikova, L.; Fouchier, R.A.; et al. Identification of a novel coronavirus in patients with severe acute respiratory syndrome. N. Engl. J. Med. 2003, 348, 1967-1976. [CrossRef] [PubMed]

5. Zhong, N.S.; Zheng, B.J.; Li, Y.M.; Poon, Z.H.X.; Chan, K.H.; Li, P.H.; Tan, S.Y.; Chang, Q.; Xie, J.P. Epidemiology and cause of severe acute respiratory syndrome (SARS) in Guangdong, People's Republic of China, in February, 2003. Lancet 2003, 362, 1353-1358. [CrossRef]

6. Zaki, A.M.; van Boheemen, S.; Bestebroer, T.M.; Osterhaus, A.D.; Fouchier, R.A. Isolation of a novel coronavirus from a man with pneumonia in Saudi Arabia. N. Engl. J. Med. 2012, 367, 1814-1820. [CrossRef]

7. WHO. Coronavirus Disease (COVID-19) Dashboard. 2021. Available online: https:/ / www.who.int (accessed on 29 June 2021).

8. Wenzel, R.P.; Hendley, J.O.; Davies, J.A.; Gwaltney, J.M., Jr. Coronavirus infections in military recruits. Three-year study with coronavirus strains OC43 and 229E. Am. Rev. Respir. Dis. 1974, 109, 621-624. [PubMed]

9. Beidas, M.; Chehadeh, W. Effect of Human Coronavirus OC43 Structural and Accessory Proteins on the Transcriptional Activation of Antiviral Response Elements. Intervirology 2018, 61, 30-35. [CrossRef]

10. Resta, S.; Luby, J.P.; Rosenfeld, C.R.; Siegel, J.D. Isolation and propagation of a human enteric coronavirus. Science 1985, 229, 978-981. [CrossRef]

11. Riski, H.; Hovi, T. Coronavirus infections of man associated with diseases other than the common cold. J. Med. Virol. 1980, 6, 259-265. [CrossRef]

12. McIntosh, K.; Chao, R.K.; Krause, H.E.; Wasil, R.; Mocega, H.E.; Mufson, M.A. Coronavirus infection in acute lower respiratory tract disease of infants. J. Infect. Dis. 1974, 130, 502-507. [CrossRef]

13. Morfopoulou, S.; Brown, J.R.; Davies, E.G.; Anderson, G.; Virasami, A.; Qasim, W.; Chong, W.K.; Hubank, M.; Plagnol, V.; Desforges, M.; et al. Human Coronavirus OC43 Associated with Fatal Encephalitis. N. Engl. J. Med. 2016, 375, 497-498. [CrossRef] [PubMed]

14. Yeh, E.A.; Collins, A.; Cohen, M.E.; Duffner, P.K.; Faden, H. Detection of coronavirus in the central nervous system of a child with acute disseminated encephalomyelitis. Pediatrics 2004, 113, e73-e76. 
15. Roulston, A.; Marcellus, R.C.; Branton, P.E. Viruses and apoptosis. Annu. Rev. Microbiol. 1999, 53, 577-628. [CrossRef]

16. Zhang, J.; Han, Y.; Shi, H.; Chen, J.; Zhang, X.; Wang, X.; Zhou, L.; Liu, J.; Zhang, J.; Ji, Z.; et al. Swine acute diarrhea syndrome coronavirus-induced apoptosis is caspase- and cyclophilin D-dependent. Emerg. Microbes Infect. 2020, 9, 439-456. [CrossRef]

17. Li, S.; Zhang, Y.; Guan, Z.; Li, H.; Ye, M.; Chen, X.; Shen, J.; Zhou, Y.; Shi, Z.L.; Zhou, P.; et al. SARS-CoV-2 triggers inflammatory responses and cell death through caspase-8 activation. Signal Transduct. Target Ther. 2020, 5, 235. [CrossRef]

18. Collins, A.R. Induction of apoptosis in MRC-5, diploid human fetal lung cells after infection with human coronavirus OC43. Adv. Exp. Med. Biol. 2001, 494, 677-682. [PubMed]

19. Kim, Y.; Lee, C. Porcine epidemic diarrhea virus induces caspase-independent apoptosis through activation of mitochondrial apoptosis-inducing factor. Virology 2014, 460-461, 180-193. [CrossRef] [PubMed]

20. Lee, Y.J.; Lee, L. Porcine deltacoronavirus induces caspase-dependent apoptosis through activation of the cytochrome c-mediated intrinsic mitochondrial pathway. Virus Res. 2018, 253, 112-123. [CrossRef] [PubMed]

21. Razvi, E.S.; Welsh, R.M. Apoptosis in viral infections. Adv. Virus Res. 1995, 45, 1-60.

22. Zitvogel, L.; Kepp, O.; Kroemer, G. Decoding cell death signals in inflammation and immunity. Cell 2010, 140, 798-804. [CrossRef]

23. Orzalli, M.H.; Kagan, J.C. Apoptosis and Necroptosis as Host Defense Strategies to Prevent Viral Infection. Trends Cell Biol. 2017, 27, 800-809. [CrossRef] [PubMed]

24. Park, B.K.; Kim, J.; Park, S.; Kim, D.; Kim, M.; Baek, K.; Bae, J.Y.; Park, M.S.; Kim, W.K.; Lee, Y.; et al. MERS-CoV and SARS-CoV-2 replication can be inhibited by targeting the interaction between the viral spike protein and the nucleocapsid protein. Theranostics 2021, 11, 3853-3867. [CrossRef]

25. Kim, D.; Maharjan, S.; Kim, J.; Park, S.; Park, J.A.; Park, B.K.; Lee, Y.; Kwon, H.J. MUC1-C influences cell survival in lung adenocarcinoma Calu-3 cells after SARS-CoV-2 infection. BMB Rep. 2021, 54, 425-430. [CrossRef] [PubMed]

26. Hammitt, L.L.; Kazungu, S.; Welch, S.; Bett, A.; Onyango, C.O.; Gunson, R.N.; Scott, J.A.; Nokes, D.J. Added value of an oropharyngeal swab in detection of viruses in children hospitalized with lower respiratory tract infection. J. Clin. Microbiol. 2011, 49, 2318-2320. [CrossRef] [PubMed]

27. Zhu, Y.; Zhao, L.; Liu, L.; Gao, P.; Tian, W.; Wang, X.; Jin, H.; Xu, H.; Chen, Q. Beclin 1 cleavage by caspase-3 inactivates autophagy and promotes apoptosis. Protein Cell 2010, 1, 468-477. [CrossRef]

28. Favreau, D.J.; Meessen-Pinard, M.; Desforges, M.; Talbot, P.J. Human coronavirus-induced neuronal programmed cell death is cyclophilin d dependent and potentially caspase dispensable. J. Virol. 2012, 86, 81-93. [CrossRef] [PubMed]

29. Meessen-Pinard, M.; Le Coupanec, A.; Desforges, M.; Talbot, P.J. Pivotal Role of Receptor-Interacting Protein Kinase 1 and Mixed Lineage Kinase Domain-Like in Neuronal Cell Death Induced by the Human Neuroinvasive Coronavirus OC43. J. Virol. 2016, 91, e01513-16. [CrossRef]

30. Su, M.; Chen, Y.; Qi, S.; Shi, D.; Feng, L.; Sun, D. A Mini-Review on Cell Cycle Regulation of Coronavirus Infection. Front. Vet. Sci. 2020, 7, 586826. [CrossRef]

31. Cohen, G.M. Caspases: The executioners of apoptosis. Biochem. J. 1997, 326, 1-16. [CrossRef]

32. Li, J.; Yuan, J. Caspases in apoptosis and beyond. Oncogene 2008, 27, 6194-6206. [CrossRef]

33. Connolly, P.F.; Fearnhead, H.O. Viral hijacking of host caspases: An emerging category of pathogen-host interactions. Cell Death Differ. 2017, 24, 1401-1410. [CrossRef] [PubMed]

34. Koh, D.W.; Dawson, T.M.; Dawson, V.L. Mediation of cell death by poly(ADP-ribose) polymerase-1. Pharmacol. Res. 2005, 52, 5-14. [CrossRef]

35. Yang, K.; Hitomi, M.; Stacey, D.W. Variations in cyclin D1 levels through the cell cycle determine the proliferative fate of a cell. Cell Div. 2006, 1, 32. [CrossRef] [PubMed]

36. Dang, C.V. c-Myc target genes involved in cell growth, apoptosis, and metabolism. Mol. Cell. Biol. 1999, 19, 1-11. [CrossRef] [PubMed]

37. Zhou, C.; Ma, J.; Su, M.; Shao, D.; Zhao, J.; Zhao, T.; Song, Z.; Meng, Y.; Jiao, P. Down-regulation of STAT3 induces the apoptosis and G1 cell cycle arrest in esophageal carcinoma ECA109 cells. Cancer Cell Int. 2018, 18, 53. [CrossRef] [PubMed]

38. Kang, J.H.; Jang, Y.S.; Lee, H.J.; Lee, C.Y.; Shin, D.Y.; Oh, S.H. Inhibition of STAT3 signaling induces apoptosis and suppresses growth of lung cancer: Good and bad. Lab. Anim. Res. 2019, 35, 30. [CrossRef] [PubMed]

39. Halupa, A.; Bailey, M.L.; Huang, K.; Iscove, N.N.; Levy, D.E.; Barber, D.L. A novel role for STAT1 in regulating murine erythropoiesis: Deletion of STAT1 results in overall reduction of erythroid progenitors and alters their distribution. Blood 2005, 105, 552-561. [CrossRef]

40. Lin, W.; Choe, W.H.; Hiasa, Y.; Kamegaya, Y.; Blackard, J.T.; Schmidt, E.V.; Chung, R.T. Hepatitis C virus expression suppresses interferon signaling by degrading STAT1. Gastroenterology 2005, 128, 1034-1041. [CrossRef]

41. Mizutani, T.; Fukushi, S.; Murakami, M.; Hirano, T.; Saijo, M.; Kurane, I.; Morikawa, S. Tyrosine dephosphorylation of STAT3 in SARS coronavirus-infected Vero E6 cells. FEBS Lett. 2004, 577, 187-192. [CrossRef] [PubMed]

42. Chang, Z.; Wang, Y.; Zhou, X.; Long, J.E. STAT3 roles in viral infection: Antiviral or proviral? Future Virol. 2018, 13, 557-574. [CrossRef]

43. Kaye, M. SARS-associated coronavirus replication in cell lines. Emerg. Infect. Dis. 2006, 12, 128-133. [CrossRef]

44. Nicholson, D.W.; Thornberry, N.A. Caspases: Killer proteases. Trends Biochem Sci. 1997, 22, 299-306. [CrossRef]

45. Ivashkiv, L.B.; Donlin, L.T. Regulation of type I interferon responses. Nat. Rev. Immunol. 2014, 14, 36-49. [CrossRef] 
46. Ströher, U.; DiCaro, A.; Li, Y.; Strong, J.E.; Aoki, F.; Plummer, F.; Jones, S.M.; Feldmann, H. Severe acute respiratory syndromerelated coronavirus is inhibited by interferon-alpha. J. Infect. Dis. 2004, 189, 1164-1167. [CrossRef] [PubMed]

47. Zheng, C.; Zheng, Z.; Sun, J.; Zhang, Y.; Wei, C.; Ke, X.; Liu, Y.; Deng, L.; Wang, H. MiR-16-5p mediates a positive feedback loop in EV71-induced apoptosis and suppresses virus replication. Sci. Rep. 2017, 7, 16422. [CrossRef]

48. Thomson, B.J. Viruses and apoptosis. Int. J. Exp. Pathol. 2001, 82, 65-76. [CrossRef] [PubMed]

49. Heylbroeck, C.; Balachandran, S.; Servant, M.J.; DeLuca, C.; Barber, G.N.; Lin, R.; Hiscott, J. The IRF-3 transcription factor mediates Sendai virus-induced apoptosis. J. Virol. 2000, 74, 3781-3792. [CrossRef] [PubMed]

50. Yeganeh, B.; Ghavami, S.; Rahim, M.N.; Klonisch, T.; Halayko, A.J.; Coombs, K.M. Autophagy activation is required for influenza A virus-induced apoptosis and replication. Biochim. Biophys. Acta Mol. Cell. Res. 2018, 1865, 364-378. [CrossRef]

51. Gioti, K.; Kottaridi, C.; Voyiatzaki, C.; Chaniotis, D.; Rampias, T.; Beloukas, A. Animal Coronaviruses Induced Apoptosis. Life 2021, 11, 185. [CrossRef]

52. Lai, Y.; Wang, M.; Cheng, A.; Mao, S.; Ou, X.; Yang, Q.; Wu, Y.; Jia, R.; Liu, M.; Zhu, D.; et al. Regulation of Apoptosis by Enteroviruses. Front. Microbiol. 2020, 11, 1145. [CrossRef]

53. Li, F.Q.; Tam, J.P.; Liu, D.X. Cell cycle arrest and apoptosis induced by the coronavirus infectious bronchitis virus in the absence of p53. Virology 2007, 365, 435-445. [CrossRef] [PubMed]

54. Bressy, C.; Droby, G.N.; Maldonado, B.D.; Steuerwald, N.; Grdzelishvili, V.Z. Cell Cycle Arrest in G2/M Phase Enhances Replication of Interferon-Sensitive Cytoplasmic RNA Viruses via Inhibition of Antiviral Gene Expression. J. Virol. 2019, 93, e01885-18. [CrossRef]

55. De Martino, L.; Marfé, G.; Longo, M.; Fiorito, F.; Montagnaro, S.; Iovane, V.; Decaro, N.; Pagnini, U. Bid cleavage, cytochrome c release and caspase activation in canine coronavirus-induced apoptosis. Vet. Microbiol. 2010, 141, 36-45. [CrossRef] [PubMed]

56. Liu, C.; Xu, H.Y.; Liu, D.X. Induction of caspase-dependent apoptosis in cultured cells by the avian coronavirus infectious bronchitis virus. J. Virol. 2001, 75, 6402-6409. [CrossRef] [PubMed]

57. Hui, K.P.; Li, H.S.; Cheung, M.C.; Chan, R.W.; Yuen, K.M.; Mok, C.K.; Nicholls, J.M.; Peiris, J.S.; Chan, M.C. Highly pathogenic avian influenza H5N1 virus delays apoptotic responses via activation of STAT3. Sci. Rep. 2016, 6, 28593. [CrossRef]

58. Chandra, V.; Kar-Roy, A.; Kumari, S.; Mayor, S.; Jameel, S. The hepatitis E virus ORF3 protein modulates epidermal growth factor receptor trafficking, STAT3 translocation, and the acute-phase response. J. Virol. 2008, 82, 7100-7110. [CrossRef] [PubMed]

59. Park, B.K.; Kim, D.; Park, S.; Maharjan, S.; Kim, J.; Choi, J.K.; Akauliya, M.; Lee, Y.; Kwon, H.J. Differential Signaling and Virus Production in Calu-3 Cells and Vero Cells upon SARS-CoV-2 Infection. Biomol. Ther. 2021, 29, 273-281. [CrossRef]

60. Bitzer, M.; Prinz, F.; Bauer, M.; Spiegel, M.; Neubert, W.J.; Gregor, M.; Schulze-Osthoff, K.; Lauer, U. Sendai virus infection induces apoptosis through activation of caspase-8 (FLICE) and caspase-3 (CPP32). J. Virol. 1999, 73, 702-708. [CrossRef] [PubMed] 